\title{
COMMENTS
}

\section{ECONOMICS AWRY: USING ACCESS FEES FOR CASELOAD DIVERSION}

\author{
MARTIN D. BeIER $\dagger$
}

\section{The Problem}

Something can be heard in the hallways outside the nation's courtrooms that has not been heard for a long while-the sounds of the courtroom doors swinging closed. In recent legislation, Congress has both raised the filing fees for cases filed in federal court, ${ }^{1}$ and raised the minimum amount in controversy requirement for diversity cases. ${ }^{2}$ The impetus behind these actions comes from members of the federal bench, among others, who believe that the nation's courts are overloaded and that, as a result, the quality of justice is suffering. Thus, the argument goes, the demand for judicial services must be decreased to alleviate the caseload crunch.

This "caseload" argument suggests that those who benefit from litigation in federal court do not bear the costs. Because the fees that control access to the judiciary are far below the actual cost of providing judicial services, taxes must make up the difference. Proponents of the Law and Economics movement believe that the marginal cost of litigation should be transferred to those who use the courts' services, rather than remaining with the taxpayers.

This Comment examines the above proposition and demonstrates that, although the economic analysis has internal consistency, the "caseload" argument carries significant, but hidden, normative "baggage." More importantly, the argument for fee increases is improperly couched in procedural terms, and thereby obfuscates the

† B.A. 1987, University of California, Riverside; J.D. Candidate 1990, University of Pennsylvania.

1 See Act of Oct. 18, 1986, Pub. L. No. 99-500, 100 Stat. 1783, 1783-64 (codified as amended at 28 U.S.C. $\$ 1914$ (a) (Supp. V 1987)) (increasing filing fee from $\$ 60$ to $\$ 120)$.

2 See Judicial Improvements and Access to Justice Act, Pub. L. No. 100-702, 102 Stat. 4642,4646 (1988) (to be codified as amended at 28 U.S.C. $\S 1332$ ) (raising minimum amount in controversy from $\$ 10,000$ to $\$ 50,000$ ). 
substantive issues that should be discussed before any increases are contemplated in the future. Furthermore, the argument suffers from "tunnel vision" in that key noneconomic costs are not imputed by a characterization of federal litigation as a merely private good. By focusing on the role that federal litigation plays in society, this Comment argues that as a distributional matter, federal litigation is properly treated more like a public good than a private good.

Part II of this Comment explains the constitutional framework within which the question of access is posed. It details the Supreme Court's limitations upon constitutionally-based "right of access" arguments. This analysis shows that the Supreme Court has yet to define the constitutional perimeters of access rights to the federal courts. Part III describes the proposition that access to courts should be restricted in response to caseload burdens and examines the distributional approach that this proposition suggests. In Part IV, the economic and other flaws inherent in the caseload argument are discussed. This critique also uncovers the underlying normative framework employed by those who would restrict access and demonstrates the impropriety of presenting the proposition in the guise of a procedural remedy. The need to alter the method of classifying federal litigation as either a public or private good is then shown to be a prerequisite to any cost-minimization analysis. This discussion, in turn, reveals the costs of both approaches. Finally, the practical and policy-based reasons for classifying federal litigation as a public good are discussed. ${ }^{3}$

\section{The Constitutional Framework: Boddie and Beyond}

Unlike criminal litigation, there is great uncertainty whether a constitutionally based "right of access" to the courts exists for civil litigants. Although the law provides criminal defendants limited constitutional rights of access, ${ }^{4}$ the rights of civil litigants are ill defined. The most that can be said of the civil "right of access" question is that the Supreme Court has decided not to decide it.

Civil litigants have used three constitutional approaches when asserting a right of court access. These approaches rely on the first

3 To a limited extent, the discussion which follows is also applicable to amount in controversy minimums, but unless otherwise specified, such minimums should be considered outside the scope of the discussion.

4 See infra note 14 and accompanying text. 
amendment, ${ }^{5}$ the equal protection clause, ${ }^{6}$ and the due process clauses. $^{7}$

"Right of access" advocates, relying on the first amendment's protection of the right to petition the government for redress of grievances, saw initial acceptance of their position in dicta in NAACP v. Button, ${ }^{8}$ and later in United Transportation Union v. State Bar. ${ }^{9}$ Although never rejecting this approach outright, the Supreme Court seems to have abandoned it. The argument that the holdings of these cases rest more appropriately on freedom of association issues ${ }^{10}$ does not adequately explain this apparent abandonment. Whatever vitality the approach once had, it is now obsolete under recent Supreme Court limitations on court access. ${ }^{11}$

Similarly, early attempts to ground a right of access on the equal protection clause made some headway. Under equal protection analysis, the use of restrictive court access fees ${ }^{12}$ clearly classifies persons according to their ability to pay; yet, just as clearly, the Supreme Court has declined to find classifications based on wealth inherently suspect. ${ }^{13}$ Thus, the issue in an equal protection analysis becomes whether or not a fundamental interest is impaired.

To date, the Supreme Court has recognized equal protection based rights of access for criminal defendants only. ${ }^{14}$ Although the

5 See U.S. Const. amend. I.

6 See U.S. ConsT. amend. XIV.

7 See U.S. Consr. amends. V, XIV.

8371 U.S. 415,430 (1963) (stating that "litigation may well be the sole practicable avenue open to a [racial] minority to petition for redress of grievances").

9401 U.S. 576, 585-86 (1971) (stating that "collective activity undertaken to obtain meaningful access to the courts is a fundamental right within the protection of the First Amendment").

10 See Note, Due Process, Court Access Feés, and the Right to Litigate, 57 N.Y.U. L. REv. 768,773 n.32 (1982) [hereinafter Note, Right to Litigate].

11 See text accompanying note 18 .

12 In referring to "access fees," this Comment generally equates filing and user fees. Although not technically accurate, the former being an "up-front" charge while the latter may be "up-front" or charged on a "per hour" or similar basis, the literature on court access makes no distinction. None will be drawn here either, because the ability to pay, not the timing of the payment, is the relevant issue.

Is See, e.g., Maher v. Roe, 432 U.S. 464, 471 (1977) (“[T]his Court has never held that financial need alone identifies a suspect class for purposes of equal protection analysis."); San Antonio Indep. School Dist. v. Rodriguez, 411 U.S. 1, 2829 (1973) (refusing to recognize wealth as a suspect classification requiring strict scrutiny for equal protection purposes).

14 See, e.g., Bounds v. Smith, 430 U.S. 817, 828 (1977) (holding that the fourteenth amendment provides a "fundamental constitutional right of access to the courts [which] requires prison authorities to assist inmates in the preparation and filing of . . . legal papers"); Douglas v. California, 372 U.S. 353, 357-58 (1963) (holding that the fourteenth amendment guarantees indigent individuals a right to 
Court has found fundamental interests in the right to travel ${ }^{15}$ and the right to vote, ${ }^{16}$ the Court has never deemed the right of court access to be fundamental. ${ }^{17}$

With the first amendment approach abandoned, and the equal protection approach stonewalled, civil claimants have focused on the due process clause. Moreover, recent developments exemplified by Logan v. Zimmerman Brush Co. ${ }^{18}$ indicate that future "right of access" analysis will be confined there. In Logan, the Court defined the right of access to the courts for civil matters as a procedural due process issue. ${ }^{19}$

Before Logan, the Due Process-based "right to access" argument focused on a trilogy of cases: Boddie $v$. Connecticut, ${ }^{20}$ in which the Court struck down a filing fee preventing an indigent from obtaining a divorce; ${ }^{21}$ United States $v$. Kras, ${ }^{22}$ in which the Court upheld the

provision of counsel to appeal a criminal conviction); Griffin v. Illinois, 351 U.S. 12, 19 (1956) (holding that due process and equal protection were violated when indigent criminal defendants could not obtain adequate appellate review because they were unable to pay for transcripts of their trials).

15 See Shapiro v. Thompson, 394 U.S. 618, 629 (1969) (holding a statutory prohibition of welfare benefits to those who are residents of a state for less than a year to be an unconstitutional impediment to the right to travel).

16 See Harper v. Virginia Bd. of Elections, 383 U.S. 663, 670 (1966) (holding Virginia's poll tax unconstitutional). For an equal protection argument that the right of access to the courts is inherently no different from the right to vote, see Michelman, The Supreme Court and Litigation Access Fees: The Right to Protect One's Rights - Part II, 1974 Duke L.J. 527, 534-40. Note, however, that the Supreme Court has never explicitly addressed such an argument.

17 See, e.g., Note, Forum Non Conveniens in the Absence of an Alternative Forum, 86 Colum. L. Rev. 1000, 1013 (1986) [hereinafter Note, Forum Non Conveniens] (explaining that " $[w]$ hile access to civil court is not itself a fundamental right, a claim which is brought to vindicate a 'fundamental interest' is protected by substantive due process"); Note, The Constitutionality of Excluding Desegregation from the Legal Services Program, 84 Colum. L. Rev. 1630, 1638 (1984) (concluding that pursuant to Supreme Court precedent, the failure to provide legal assistance so as to allow access to the courts does not violate the equal protection clause); Comment, Mandatory Mediation: California Civil Code Section 4607, 33 EMORY L.J. 733, 760 (1984) (arguing that the Supreme Court in Boddie v. Connecticut, 401 U.S. 371 (1971), "implied that access to the courts is not a 'fundamental right' in most civil cases because the parties have alternate means for dispute resolution in the private sector") (footnote omitted); Note, Right to Litigate, supra note 10, at 777 (stating that "[t]he Court has been unwilling . . . to extend [an] acces.s right on equal protection grounds beyond the area of criminal appeals").

18455 U.S. 422 (1982).

19 See id. at 429-30. Interestingly, the Court characterized the access right as a property interest. See id.

20401 U.S. 371 (1971).

21 See id. at 374.

22409 U.S. 434 (1973). 
validity of a filing fee challenged by an indigent seeking access to bankruptcy court; ${ }^{23}$ and Ortwein v. Schwab, ${ }^{24}$ in which the Court upheld a filing fee challenged by indigents appealing a reduction of their welfare benefits. ${ }^{25}$ The discussion of these three cases has been extensive, ${ }^{26}$ and most of it need not be repeated here. Most commentators agree that two basic propositions can be distilled from these cases: "First, waiver of access fees is required only if the right sought to be enforced through the courts is fundamental, and second, that waiver is required only when the courts provide the sole means of vindicating that right." 27

Despite this narrow distillation and the subsequent economically oriented reshaping of due process in Matthews $v$. Eldridge, ${ }^{28}$ the constitutional right of access arguments, while diminished, are not dead. ${ }^{29}$ But the restriction of the access argument to due process in Logan, coupled with the Court's refusal to enunciate a doctrine tying any of the aforementioned strands into a coherent whole, will surely keep the civil litigant's status in limbo for the foreseeable future.

Thus, no clearly defined constitutional civil right of access to the courts is recognized. Indeed, even were one to exist, under any of the above variations, it arguably would not be exclusive to the federal courts. This Comment's focus, therefore, is "non-constitutional," although some of the arguments may have relevance to the constitutional debate. With these perimeters in mind, this Comment shall examine the specifics of the "caseload" argument in support of increasing federal court access fees.

\section{The Proposition}

The basic premise of the "caseload crisis" proposition (hereinaf-

23 See id. at 450.

24410 U.S. 656 (1973) (per curiam).

25 See id. at 658-59.

26 See, e.g., Leubsdorf, Constitutional Civil Procedure, 63 TEx. L. Rev. 579 632-33 (1984); Slawson, The Right to Protection from Air Pollution, 59 S. CAL. L. REv. 672 (1986); Note, Right to Litigate, supra note 10; Note, Forum Non Conveniens, supra note 17, at 1008-12, 1114-18.

27 Note, Right to Litigate, supra note 10, at 770.

28424 U.S. 319 (1976).

29 See, e.g., Note, Right to Litigate, supra note 10, at 793-803 (arguing that the Matthews analysis is flexible enough to allow for a right of access in certain circumstances); Note, Expanding the Due Process Rights of Indigent Litigants: Will Texaco Trickle Down?, 61 N.Y.U. L. REv. 463, 497-504 (1986) (arguing that Texaco, Inc. v. Pennzoil Co., 784 F.2d 1133 (2d Cir. 1986), rev'd on other grounds, 481 U.S. 1 (1987), has "legal significance" beyond its facts that paves the way for a due process based right of access for indigents). 
ter "Proposition") is that federal courts are overwhelmed by cases attracted to the federal forum by below-cost access fees. Thus, it is argued, court access fees should be raised significantly to divert cases elsewhere. Proponents of the "litigation explosion" theory attribute the tremendous surge in the volume of cases being filed in federal court to a number of factors, including: the broadening of substantive rights; ${ }^{30}$ the relaxation of standing requirements; ${ }^{31}$ the civil rights movement; ${ }^{32}$ the routine approval of in forma pauperis ("I.F.P") petitions; ${ }^{33}$ and various other causes. Although many of these factors have indeed influenced the workload of the federal judiciary, there remains a legitimate dispute over the scope and actual impact of these factors. ${ }^{34}$ For present purposes, however, one need not take sides in this dispute. The discussion below is relevant whether court overcrowding is an accomplished fact or remains merely a possibility. To be most fair to proponents of the Proposition, this Comment assumes the existence of the litigation explosion and proceeds from there.

According to economists, all resources are scarce, including judicial services. The rational approach to scarcity is to allocate these resources as efficiently as possible so that the greatest benefit can be derived from their expenditure. Also, under economic theory, minimizing costs is equivalent to maximizing benefits; therefore,

30 See Attanasio, Symposium on the Fiftieth Anniversary of the Federal Rules of Civil Procedure - Foreword: A Duty-Oriented Procedure in a Rights-Oriented Society, 63 NoTRE DAME L. REv. 597, 599-602 (1988) (discussing the effect of the litigation resulting from broadened substantive rights in the Federal Rules); Hill \& Baker, Dam Federal Jurisdiction! 32 EMORY L.J. 3, 56 (1983) (noting that the broadening of doctrine causes increases in litigation as "courts struggle for consistency and clarity").

31 See Hill \& Baker, supra note 30 , at 8 (stating that "[p]ublic law litigiousness responds to changing perceptions of both the likelihood of prevailing and the opportunity to litigate itself").

32 See Smith, Lawyers Split the Fee and Taxpayers Foot the Bill, Wall St. J., Feb. 25, 1986, at 30, col. 3 (describing civil rights attorney fee awards as a "massive national giveaway"). But see, Galanter, The Day After the Litigation Explosion, 46 MD. L. Rev. 3, 18-28 (1986) (acknowledging that civil rights decisions and legislation have increased court docket loads, but questioning the presumptions of the "litigation explosion" theory).

33 See Note, Controlling and Deterring Frivolous In Forma Pauperis Complaints, 55 Fordham L. Rev. 1165, 1175-79 (1987) (arguing that the flood of meritless I.F.P. complaints are best addressed through prefiling dismissals).

34 See Galanter, Reading the Landscape of Disputes: What We Know and Don't Know (and Think We Know) About Our Allegedly' Contentious and Litigious Society, 31 UCLA L. REv. 4 (1983). 
the task of optimal resource allocation is often characterized as a cost-minimization approach. ${ }^{35}$

The general Law and Economics model treats judicial services, including court access, in the same manner as any consumable good, e.g., a loaf of bread. ${ }^{36}$ Applying economic theory to federal court usage, the supply of federal court access is dictated by the maximum number of cases that can be handled adequately by the present composition of federal judges, courtrooms, and the accompanying bureaucracy. In the short run, the supply of judicial services is fixed (assuming that operation is already at full capacity), because the number of judges and courtrooms cannot be changed immediately. Increases in capacity require future changes in the federal budget. Free market competition would bid the price of access up until enough litigants deserted to other forums of dispute resolution that the demand decreased to equal the cost of the level of judicial services supplied. ${ }^{37}$

Obviously, this model contains imperfections and over-simplifications. For instance, the model assumes perfect information to all parties, as well as the availability of viable substitutes to lure litigants away. Despite these imperfections, the model is useful in economic analysis for making general predictions about behavior. Because the access fees litigants currently pay are significantly less than the total budget of the federal judiciary, it is clear that the taxpayers are "subsidizing" the shortfall. Thus, Proposition proponents call for a radical increase in court access fees to charge users (usually defined as all litigants) with the amount expended on supplying them with federal judicial services.

There are several variations of the above argument. The unelected spokesman of Proposition proponents is Judge Posner of the Seventh Circuit. Judge Posner believes that the size of the federal judiciary, even in the long run, is relatively fixed by the very structure of the United States judicial system, which impedes further

35 See E. DOLAN, BASIC Economics 14 (3d ed. 1983) (defining efficiency as minimizing expense).

36 Capitalist economic theory states that in a free market, the price charged for any particular good is dictated by the interplay between a good's supply and demand functions. When supply and demand do not correlate, adjustments occur. If supply cannot be altered, and demand exceeds supply, the theory dictates that the price of the good will be competitively bid up, pushing out of the market those who value the good less than the price. In the end, the theory states, the demand will exactly equal the supply at the "market equilibrium" price. See id. at 56-64.

37 This application of theory also assumes that the government providing judicial services is not adjudicating for a profit. 
expansion of adjudicatory capacity. ${ }^{38}$ Most significantly, Posner believes that increasing the supply of judges will 1) create detrimental delay in developing a consensus in en banc and panel decisions; 2) create an increase in the number of decisions, creating a greater number of inter-circuit conflicts; and 3) detract so significantly from the prestige of a federal judgeship that the best qualified persons will seek employment elsewhere. ${ }^{39}$ According to Posner, any (or all) of these eventualities would lower the quality of federal court output which, in turn causes higher uncertainty about what the law is, consequently spurring even greater increases in the amount of litigation. Thus, the addition of more judges and courts complicates the resolution of disputes and cheapens the utility of the "product." 40

Judge Posner, however, does not advocate removing the entire subsidy. Rather, he would permit cases filed under the in forma pauperis statute ${ }^{41}$ to remain in federal court, but would squeeze out, by increased access fees, those cases brought by people who are not indigent but are unable to pay for the judicial services they consumed. ${ }^{42}$ Presumably, these would be cases involving small monetary stakes, as the increase in court access fees would make the litigation economically unfeasible. But here, too, Posner still leaves some subsidy, recognizing adjudications have externalities ${ }^{43}$ that benefit those besides the parties to a dispute. The general public, in fairness, would be taxed for this benefit transfer. ${ }^{44}$

The significance of Posner's approach is that, apart from the in forma pauperis cases, only those litigants contesting large sums of money would be in federal court. Posner claims this is appropriate because:

they [litigants who have a large stake] are the best kind of litigants to have in a court system. ... [I]f great cases and hard cases make bad law, financially significant cases make good law. The bigger

38 See R. Posner, The Federal Courts: Crisis and Reform 99-102 (1985).

39 See id. at 99.

40 See id. at 99-102. Professor Kenneth Scott similarly argues that the addition of judges could worsen the situation, because as additional judges are added, "delay costs are reduced, which in turn brings additional cases into the system." Scott, Standing in the Supreme Court - A Functional Analysis, 86 HARv. L. REv. 645, 672 (1973).

41 Pub. L. No. 96-82, \& 6, 93 Stat. 645 (1979) (codified as amended at 28 U.S.C. $\S 1915$ (1982)).

42 See R. Posner, supra note 38, at 132.

43 An "externality" in economic theory is defined as "a favorable [or unfavorable] effect on one or more persons that emanates from the action of a different person ...." P. SAMUizson, EConomics 476 (10th ed. 1976) (emphasis omitted).

44 See R. Posner, supra note 38, at 131-32. 
the financial stakes in a case, the greater are the legal resources that will be expended on the case; and the more informed the judge is on the law and facts as a result of the parties' efforts, the more likely he is to render a sound decision.... The larger the stakes in the case (or cases) in which the rule is established, the more likely it is to be a sound one; and many holders of small as well as large federal claims will benefit if the edifice of federal judge-made law is well built. ${ }^{45}$

Thus, Posner believes that for federal litigation, "bigger is better." Accordingly, he argues, the scarcity of federal judicial resources demands increased federal court access fees so that judges will create better law by spending their time on high stakes cases.

Former Solicitor General Rex E. Lee presents another variation of the Proposition. ${ }^{46}$ Restating the Proposition, Lee asserts that: "[judicial] services are consumable. Use by one has effect on others' use. And since everyone does not use the courts in direct proportion to the taxes he or she pays, public financing makes it not only possible but inevitable that some will pay for what others use." 47

Since Lee finds that "in the case of the overwhelming majority of litigants, consumption of judicial resources results not from any altruistic or public-spirited effort to advance the common good,"48 a change from public financing to user financing, presumably through increased access fees, is warranted. Although Lee acknowledges that "the use of the courts is not provided at public expense alone," 49 citing legal fees and other costs as barriers to litigation, he insists that this merely proves "that the subsidy is not complete," and the subsidy alone measurably contributes to the overuse of the court system. ${ }^{50}$

Curiously, Lee initially appears to be motivated by public welfare concerns:

Why, for example, should the public subsidize a lawsuit between Greyhound and IBM, or between Litton Industries and AT\&T? Surely others are in more need of public welfare benefits. Yet in each of those suits the public paid the bill for thousands of hours of

45 Id. at 132-34.

46 See Lee, The American Courts as Public Goods: Who Should Pay the Costs of Litigation?, 34 CATH. U.L. REv. 267 (1985).

47 Id. at 268.

48 Id.

49 Id. at 270.

50 Id. 
court time-at several hundred dollars per hour-to determine which of these corporate giants owed the other money. ${ }^{51}$

But after acknowledging that "the case for the public funding of courtroom costs for poor people is stronger than for people of means," 52 he nevertheless argues that indigency exemptions from increased court access fees do not necessarily follow. The general rule, Lee argues, should be to deny such exemptions, leaving to affirmative legislative action the decision to create any exemptions. ${ }^{53}$

Lee also discusses exemptions for "public interest cases," due to the externalities they produce. But unlike Posner, Lee argues that the existence of externalities does not require that some subsidy be allowed:

For while nonmonetary suits frequently yield nonmonetary values to persons other than the plaintiff and defendant, they are values that are not shared by all who finance the litigation through their taxes. ... As strong as the public interest is in vindicating a clean environment or strong civil rights laws, for example, it is not always easy to ascertain which side in a particular lawsuit best achieves those objectives, or whether the cost at which they are achieved makes the suit a net contribution or detriment to the public interest. ${ }^{54}$

Thus, he continues, "the cost of running the courts . . should be borne (as the legal fee component is currently borne) by organizations whose members believe in the organizational objectives." 55 In essence, then, Lee finds that "public interest" litigation is best left in the hands of organizations of like-minded individuals, and these organizations should then bear the full cost of their litigation, including access fees. Thus, Lee, unlike Posner, would charge full access fees to all, unless the legislature made an affirmative decision to do otherwise. ${ }^{56}$

Other variations of the Proposition can be found, ${ }^{57}$ but these two define the extreme boundaries. Court access fee exemptions, if

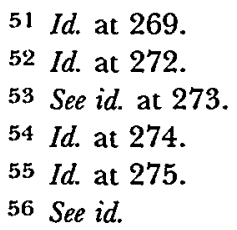

57 See, e.g., G. Tullock, Trials on Trial: The Pure Theory of legal Procedure 156-58 (1980) (discussing a system in which litigants pay a fee per minute of court time or labor, which would approximate the "social cost of the court facilities"). 
ever considered in the economic analysis, only apply to indigents or public interest cases.

Focusing exclusively on the federal courts, one must ask: under the above Proposition (and variations), where would would-be litigants go if federal court access fees were drastically increased? Clearly, the state courts would receive the first wave of diverted cases. Indeed, Posner extols the virtues of this diversion:

The question is not one of denying access to the courts but of shifting litigants from one court system (the federal) to others (the state court systems) which are forbidden by the Constitution to close their doors to persons wanting to litigate federal claims in state court. . . . An equal number of people having federal claims of small value may benefit as may lose if size of claim is used, directly or indirectly, to ration access to federal courts. The rules the federal courts lay down are rules for big and small claims alike, even if the latter claims are litigated in state courts-but applying federal law-rather than in federal courts. ${ }^{58}$

To the charge that such shifting would unfairly burden the state courts, Posner replies, "there is a fundamental difference between the overcrowding problems of the federal court system and those of the state court systems" due to the disparity in their sizes. Thus, he argues, "the same percentage reduction in the federal caseload... shift[ed] to the states will cause a much smaller percentage increase in state caseloads."

Conceivably, though, state courts will follow suit and increase their court access fees, sending would-be litigants packing again. Anticipating this possibility, Posner states:

[S]ome of the federal cases would be shunted to private arbitration, especially if the states followed the lead of the federal government and raised their court filing fees. Admittedly, if they did, there would be a danger of overdiscouraging litigation, especially by persons just above the indigence level. But this is not an imminent danger; and even if some state courts begin to charge stiff filing fees, others-small claims courts, for example-will not. ${ }^{60}$

Thus, even if a number of cases that are presently litigated by choice in the federal courts are diverted to other courts, or even "non-judicial" adjudication systems (such as alternative dispute resolution

58 R. POSNER, supra note 38 , at 133-34 (footnote omitted).

59 Id. at 134.

$60 \mathrm{Id}$. 
institutions, hereinafter "ADR"), proponents of the Proposition find no real harm to those litigants.

Several rationales (other than cost reclamation) are offered in defense of diverting cases out of federal court through increased access fees. First, user-based access fees, which affect all types of cases, are preferable to raises in the jurisdictional minimum amount in controversy, which affect only diversity cases in federal courts, because "where [user] fees are employed the courts need not engage in the often inefficient and fruitless task of attempting to measure the immeasurable." 61 Second, diversion is justified for the information it provides "about the elasticity of demand for various types of federal judicial services." 62 And finally, catering only to paying parties might, through generation of excess revenue, provide legislators with funds to correct any clistributional problems through the creation of increased judicial capacity. ${ }^{63}$

\section{RefiJting the Proposition}

\section{A. Stripping the Procedural Cloak: The Adverse Effects}

From a broad perspective, one cannot help but observe that: "Caseload reduction is a rather odd basis for a radical redistribution of the respective roles of federal and state courts or for major changes in federal substantive law. Such measures would seem weakly justified by caseload considerations alone." 64 In addition, because a number of barriers to court access already exist, compelling justifications should be required before the judicial system heeds the call for new ones. Besides legal fees themselves, there remain geographic, ${ }^{65}$ time,${ }^{66}$ and psychological impediments. ${ }^{67}$ Further, one should suspect "procedural" reforms that seem to counter the spirit of the federal rules governing civil cases. If, indeed, "the

61 Redish, The Federal Courts, Judicial Restraint, and the Importance of Analyzing Legal Doctrine (Book Review), 85 ColuM. L. Rev. 1378, 1388 (1985).

62 R. Posner, supra note 38 , at 136.

63 Scott, supra note 40 , at 682 .

64 Estreicher, Conserving the Federal Judiciary for a Conservative Agenda? (Book Review), 84 Mich. L. Rev. 569, 577 (1986).

65 Courts and large law firms are inevitably located in inner-city locations. See Abel, Law Without Politics: Legal Aid Under Advanced Capitalism, 32 UCLA L. Rev. 474, 488 (1985).

66 The "9 to 5" routine of most courts and attorneys requires those seeking access to leave their own jobs, at some expense. See id.

67 Despite the "litigation explosion," some people remain intimidated by courts and attorneys. See id. at 488-89. 
Federal Rules [of procedure] were intended by their drafters to open wide the courthouse doors ... to a civil practice in which all parties would have ready access to the courts and to relevant information, "68 one properly questions "reformist" approaches that, in essence, rescind the offer that the drafters made.

In addition to these logical flaws, there are also a number of tangible effects of case diversion that are neglected or ignored by the Proposition. An examination of these adverse effects establishes the need to re-examine the Proposition. The adverse effects of case diversion fall heaviest on parties with federal questions involving small monetary stakes. This is especially true where federal courts have jurisdiction exclusive of the states. As mentioned by Professor Alschuler, "[s]ubstantially increased filing fees in the federal courts might not be objectionable if state-court filing fees remained low and if areas of exclusive federal jurisdiction were exempt from filing-fee requirements."69 Costs from diversion occur because, as Professor Redish notes, "[u]sually, the federal courts have been provided jurisdiction for a purpose, and any reduction in either their jurisdiction or in litigant access to the courts will itself impose a cost."70 By claiming that diversion is harmless, proponents of the Proposition necessarily assume that the often expressed concern about "the good faith and ability of the state courts" to protect federal rights, even to the detriment of state's rights, no longer applies. ${ }^{71}$ But as no basis for this assumption has been established, longstanding concerns about the efficacy of the state courts in administering federal law cannot facilely be dismissed.

Furthermore, in seeking to alter the composition of federal casework, Proposition proponents are, in effect, substituting their judgment for that of Congress and the Founders who have "deemed a particular interest to be of great significance."72 Surely "the inability to translate that interest directly into a financial measure should not [be permitted to] preclude its protection and enforcement in federal courts."73 Advocates of diversion who equate monetary stakes with the need to litigate in federal court fails to appreciate the under-

68 Weinstein, After Fifty Years of the Federal Rules of Civil Procedure: Are the Barriers to Justice Being Raised?, 137 U. PA. L. REv. 1901, 1906 (1989).

69 Alschuler, Mediation with a Mugger: The Shortage of Adjudicative Services and the Need for a Two-Tier Trial System in Civil Cases, 99 HARv. L. REv. 1808, 1812 n.1 1 (1986).

70 Redish, supra note 61 , at 1386.

71 Id. at 1391.

72 Id. at 1388.

73 Id. 
lying "nature of the specific substantive federal rights" so excluded. ${ }^{74}$

It is ironic, considering Judge Posner's position discussed above, ${ }^{75}$ that another adverse consequence arises from the numerical disparities between the fecleral and state courts. Diverting federal questions to the fifty state courts will likely increase conflicts in the interpretation of federal law to a degree greater than we now have among the thirteen federal circuits. As the United States Supreme Court is the only forum where such conflicts are resolved, and that Court cannot increase its caseload much as it is presently organized, this stands to increase confusion about what the law is. As' Posner predicted with respect to expansion of the federal judiciary, the ensuing confusion would cause more litigation. ${ }^{76}$

To the extent that there are qualitative differences between the federal and state court systems, other concerns about federal litigation diversion arise. Assuming that the federal judge is "abler" than her state counterpart, diversion of any case from federal to state court imposes inefficiency costs. Indeed, Posner, responding to this assumption, states that "some redress of the balance of power between federal and state courts is long overdue, and would be worth a small reduction in the average quality of decisions."77 Both the normative implications of this assertion, as well as the lack of empirical verification of comparative ability should give pause to those who do believe the federal bench to be "abler." Showing some reluctance to declare that federal judges are "better," Posner nevertheless recognizes that a federal forum has certain advantages, ${ }^{78}$ and "makes the implicit assumption that certain federal rights do deserve to be heard in federal rather than state court-those that are deemed by the litigant to be so valuable that he is willing to pay a high entry fee to obtain the benefits of a federal forum." 79 Thus, even Posner seems to agree that the better facilities, support, and procedural rules available in federal courts offer a more efficient environment

74 Id. at 1389.

75 See supra note 59 and accompanying text.

76 While Judge Posner mentions this concern as a potential stumbling block to his call for increased court access fees, he unsatisfactorily denigrates its importance, implying that as the extent of such costs are uncertain they are irrelevant, and stating that such concerns do not apply to diverted diversity cases. See R. PosNER, supra note 38 , at 135. While the latter argument may have merit, the former is both economically and logically unsound.

77 Id.

78 See id.

79 Redish, supra note 61 , at 1388 n.20. 
for the handling of complex cases than can be found in state courts. $^{80}$

But even without these qualitative arguments, other distinctions between the federal and state court systems reveal consequences implicit in, but not acknowledged by, the Proposition. Politics affects the resolution of cases in state courts more so than in the federal courts, which are somewhat insulated from political vagaries by the life tenure and irreducible salaries of federal judges. ${ }^{81}$ Additionally, although the diversion to the state courts of certain federal cases may not appear to have a severe impact when distributed equally among the state courts, as Posner suggests, ${ }^{82}$ certainly some states will see a greater increase, with severe repercussions for those already overwhelmed. ${ }^{83}$ And although states are required to hear federal claims, ${ }^{84}$ understandably "state courts are often not receptive to federal question arguments, particularly when the claims break new ground." 85

Shifting federal cases into ADR imposes other significant costs. Because these institutions "lack effective sanctions," 86 their "coerced" use may interpose an additional, costly step for litigants before final resolution. Costs also result from the failure to air grievances in open court and from the structure and workings of settlement-promoting institutions themselves. ${ }^{87}$ Last, one should not, as does Judge Posner, blithely dismiss the potential dangers of overdiscouraging litigation through diversion to ADR. ${ }^{88}$ One may properly question the view that small-stake federal question cases can adequately be handled by an arbitrator or a small claims court judge.

Indeed, all of the foregoing instances ignoring or downplaying

80 See Weinstein, supra note 68, at 1918.

81 See Redish, supra note 61 , at 1390-91; Weinstein, supra note 68 , at 1918. This distinction, of course, only applies to state court systems that do not have lifelong judgeships or guaranteed salaries.

82 See supra note 59 and accompanying text.

83 See Weinstein, supra note 68, at 1918.

84 But of. Redish, supra note 61 , at 1391 n.26 (noting that "[i]n certain, not always clearly defined circumstances, the Supreme Court has recognized a 'valid excuse' for a state court's refusal to hear a suit brought pursuant to a federally protected right").

85 Leubsdorf, supra note 26 , at 604.

86 Bush, Dispute Resolution Alternatives and the Goals of Civil Justice: Jurisdictional Principles for Process Choice, 1984 WIS. L. REv. 893, 899.

87 See Sarokin, Justice Rushed is Justice Ruined, 38 RuTGers L. REv. 431, 433 (1986) (noting that settlement denies the opportunity for court-enunciated guidance of future conduct and may conceal from the public discriminatory practices, patent invalidity, or the existence of a dangerous product on the market).

88 See R. POSNER, supra note 38 , at 134 . 
the full effects of litigation diversion can best be explained as the result of normative judgments about which litigants should and should not air their grievarices in a Federal forum. This is patently clear from Posner's work and easily inferred from Lee's predisposition to deny access absent affirmative legislative action.

Because proponents of the Proposition call access fee increases "procedural reform," Lee's position requiring affirmative congressional action is troubling:

Political realities discourage legislative procedural reform. The public has little grasp of civil procedure and little interest in it. Those who suffer from a bad procedural rule usually do not know in advance that they will be its victims, or even that the rule exists, and are usually scattered and disorganized. ... "[R]epeat players" such as insurance companies and installment sellers are more likely to pursue their interests through the political process than other litigants are. ${ }^{89}$

Relegation of the decision to affirmative congressional action carries its own perils.

Alternatively, one may argue that Congress has already spoken on the subject. In contrast to Lee's position that the subsidy is retained by legislative inertia ${ }^{90}$ and tradition, ${ }^{91}$ Congress recently has been concerned with opening, not closing, the courtroom doors to smaller cases. The minimum amount in controversy requirement for federal questions is one litigation-access barrier Congress affirmatively dropped. The legislative history of its amendment and subsequent repeal shows that Congress specifically intended to open the courtroom doors. Congress initially demonstrated this intent when it amended 28 U.S.C. $\S 1391$ to permit suits against the U.S. and its agencies regardless of the amount involved, stating that:

[T]here are a significant number of situations involving "non-statutory" review in which a plaintiff must still ground his action on section $1331 . \ldots$ In some of these cases the jurisdictional amount requirement cannot be met because it is impossible to place a monetary value on the right asserted by the plaintiff. $^{92}$

Later, Congress showed its continuing resolve by repealing the requirement for federal quistions altogether:

89 Leubsdorf, supra note 26 , at 613-14.

90 See Lee, supra note 46 , at 273 .

91 See id. at 267.

92 H.R. Rep. No. 1656, 94th Cong., 2d Sess. 14, reprinted in 1976 U.S. Code Cong. \& ADMIN. News 6121, 6134. 
The purpose of the ... legislation is to abolish the $\$ 10,000$ amount in controversy requirement in Federal question cases. The bill ... resolves the anomolous situation faced by persons who, although their Federal rights have been violated, are barred from a Federal forum solely because they have not suffered a sufficient economic injury. [The Bill] represents sound principles of federalism by mandating that the Federal courts should bear the responsibility of deciding all questions of Federal law. At the same time, it demonstrates an increased respect for the States by providing that Federal claims should not be forced on the overburdened State court systems. ${ }^{93}$

Thus Lee's belief that mere inertia is the rationale behind the subsidy seems ill-founded. Congress deems access to federal courts a commodity intended for a wider distribution than Lee's private good depiction would permit: "Congress is resisting the pleas of the United States Judicial Conference to abolish diversity [jurisdiction], encouraging plaintiffs to use the courts through litigation cost-shifting devices such as Section 1988 and the Equal Access to Justice provisions, and increasing standing through environmental and many other statutes."94 Indeed, this resistance, coupled with the aforementioned grants of federal jurisdiction, provides valuable insights into Congress's intended breadth of access to the federal judiciary.

This discussion of congressional intent also "underscore[s] the dubiousness of Posner's assumption that 'cases with small monetary stakes' are necessarily unworthy of a federal forum." 95 Even if Congress is not as amenable to open access arguments as the foregoing might suggest, Posner's "bigger is better" approach is still objectionable because those with higher stakes, already overrepresented through their enhanced access to Congress, should not gain a similar "monopolization" of the federal courts.

Still more troubling is the failure of Posner's general analysis to account for social costs in a meaningful way. ${ }^{96} \mathrm{He}$ writes:

The purpose of legal procedure is conceived to be the minimization of the sum of the two types of costs: "error costs" (the social costs generated when a judicial system fails to carry out the alloca-

93 H.R. REP. No. 1461, 96th Cong., 2d Sess. 1, reprinted in 1980 U.S. CodE Cong. \& ADmin. News 5063, 5063.

94 Weinstein, supra note 68, at 1906 (citation omitted); see also supra note 92 and accompanying text (regarding the elimination of the minimum amount in controversy requirements for federal question jurisdiction).

95 Redish, supra note 61, at 1388 (citation omitted) (quoting R. PosNer, supra note 38 , at 132).

96 See Bush, supra note 86 , at $929-30$. 
tive or other social functions assigned to it), and the "direct costs" (such as lawyers', judges', and litigants' time) of operating the legal dispute-resolution machinery. ${ }^{97}$

Although Posner's definition of error costs mentions social costs, in application he considers orly error costs resulting from resource misallocation. ${ }^{98}$ Thus, Posner's court access fee analysis omits key, non-economic costs.

The most disconcerting: aspect of the Proposition, however, is the use of the "procedural" label for its suggested reforms. As Judge Weinstein notes with respect to court access barriers in general:

[W] hatever the merits of reducing plaintiffs' rights, a system which denies those rights by procedural subterfuge is highly undesirable. Substantive rights should be debated in public, with a full airing of issues ... . Procedural machinations designed quietly to overload the litigation costs of plaintiffs have the effect of denying substantive rights, but without any of the procedural safeguards attached to public and legislative decision-making. ${ }^{99}$

Thus, if Congress intends to change the rules relating to court access, the discussion preceding such change must be public. Yet, just as Judge Weinstein feared, the modest changes in court filing fees of recent years, apparently made in response to the Proposition's proponents, have been accomplished through legislative sleight of hand. In 1986, for example, the federal civil filing fee increase was buried in a huge government spending bill passed immediately before adjourrment. As was observed following this unceremonious doubling of court access fees:

The lack of consensus on the likely impact [of the fee increases] reflects the scant opportunity for discussion before Congress acted. There were no public hearings on the increase. ... In addition, because the increase was treated purely as an appropriation matter, the House and Senate Judiciary Committees, which ordinarily review all legislation concerning the Federal courts, were bypassed. $^{100}$

Such an important matter as federal court access deserves more attention than the designation "procedural" would indicate. The

97 Posner, An Economic Approach to Legal Procedure and Judicial Administration, $2 \mathrm{~J}$. Legal StUd. 399, 399-400 (1973).

98 See Bush, supra note 86 , at 930 .

99 Weinstein, supra note 68 , at 1919-20.

100 N.Y. Times, Oct. 29, 1986, at A24, col. 4. 
challenge is not to the value of the cost-minimization approach, but rather to the manner in which cost-minimization has been appliedas if court fee increases are devoid of substantive concerns. But a balanced economic critique will show that other cost concerns, in addition to those noted above, deserve to be included in the costminimization equation.

\section{B. The Economic Critique}

To challenge the Proposition fairly, one should meet its authors on common ground. Although the foregoing section may have had the aspect of a critique, its purpose was to highlight the omissions made in the traditional economic model's abstraction, revealing the normative values hidden within. The Proposition shall now be challenged directly as "positive" economics.

The diversion of cases from the federal system is a negative externality ${ }^{101}$ and operates to undermine the entire allocative system. ${ }^{102}$ To the extent that cases go before state paid or privately hired adjudicators, one may anticipate a drop in the level of impartiality. Professor Alschuler notes this peril, saying: "Impartial adjudication is one of the first tasks of government. Indeed, a market that distributes other goods and services through voluntary private contracts is premised on the availability of this service."103 Admittedly, much of the aforementioned damage might be mitigated because increasing court access fees affects small stakes, rather than large stakes cases. But there are further problems with the Proposition's economics.

Utility, as an economic concept, cannot be measured, but nevertheless it should not be ignored. ${ }^{104}$ It is reasonable to assume that the more money one has, the lower the value, or utility, she will ascribe to each particular dollar; thus, the marginal utility ${ }^{105}$ of dollars declines as the amount involved increases. Access fees, there-

101 See supra note 43 (defining "externality").

102 Ironically, Judge Posner has argued that diversion of cases out of court into ADR institutions could in the long run increase litigation rates due to the "difficult[y in] predict[ing] how courts will resolve [parties'] disputes." Posner, The Summary Jury Trial and Other Methods of Alternative Dispute Resolution: Some Cautionary Observations, 53 U. CHI. L. Rev. 366, 388 (1986).

103 Alschuler, supra note 69 , at 1816-17.

104 "Utility" is defined under economic theory as "the pleasure, satisfaction, and need fulfillment that people get from the use or consumption of . . goods and services." E. Dolan, supra note 35 , at 413 .

105 "Marginal utility" is "[t]he amount of added utility obtained from a one-unit increase in consumption of a good." Id. at 414. 
fore, constitute a decidedly inefficient gauge to determine the utility of a suit to the litigant. The use of access fees as entry barriers could very well press litigants with "high utility value" stakes out, while leaving those with lower utility values in.

Moreover, raising access costs decreases the "internalization" of costs for wrongdoers:

Confronted by . . . impediments to legal redress, an injured plaintiff with a just and provalble claim for $\$ 10,000$ in damages may rationally settle for $\$ 5,000$ or some other fraction of the amount that the Hand formula seems to promise him. Were our legal system to increase the costs of justice ... the amount that the plaintiff would be likely to accept in settlement would grow smaller. Wrongdoers would be required to "internalize" a smaller portion of the cost that their conduct has inflicted on others. Their incentive to engage in improper or inefficient conduct would increase. $^{106}$

Another consideration is that the elasticity of the demand for federal adjudication may be overestimated by the Proposition. Many small stake cases continue to come to federal courts despite the formidable barriers to litigation that already exist. This indicates that anything short of an unconscionable increase in access fees will likely have little long term effect on the number of cases filed.

Related to the elasticity argument, discussion of the viability of substitutes is absent in the Proposition analyses. According to standard economic theory, if substitutes are not deemed viable, little, if any, decrease in demand will result from a price increase if the "good" cannot easily be forgone. Litigation in federal court might be forgone by "lumping it," but might also be forgone through "self help." Certain "self help" actions, however, are proscribed by society in order to avoid public disturbances and violence. In theory, then, litigants who feel state courts and ADR institutions are inferior substitutes for federal adjudication will pay the higher access fees when the penalties for prohibited self-help actions exceed those fees, but they will resort to self help measures in the converse situation. Although the end result may be a greater recovery of court costs, it may increase the amount of prohibited self-help activity, doing more aggregate damage than good. This may shift some would-be civil cases into the criminal docket. ${ }^{107}$

106 Alschuler, supra note 69, at 1814 (footnotes omitted).

107 See id. at 1815 (noting also that "[a] society that wishes its members to renounce [a] claim must make a peaceful means of adjudicating disputes available to them"). A tragic example of how lack of access in a civil case can lead to criminal 
More concretely, the bluntness of the Proposition's approach deserves mention. Specifically, the Proposition fails to recognize the need to distort individual private market decisions in favor of collective private market decisions. The former may not mirror the latter because individuals often do not consider the large-scale externalities of their decisions. ${ }^{108}$ The individual decision to litigate in federal court, even for large stakes cases, will rarely, if ever, consider broader social costs. Thus the Proposition, by influencing only individual decision makers, still leaves the imputation of social costs and possible economies of scale to the vagaries of chance.

Additionally, while increasing user fees carries few administrative costs, it may result in higher marginal costs stemming from the homogeneity of federal court cases it creates. As mentioned, raising court access fees ignores the content of the lawsuits diverted. But to allocate judicial resources efficiently, "cases that involve significant potential for furthering resource allocation should be formally adjudicated, and the system should make known the rules adopted and the fact that they are of general application."109 Because each case, regardless of size, carries within it the potential for generating allocative rules of general applicability, a fee system that skews the system toward greater homogeneity of cases will delay, if not completely prevent, the creation of allocative rules by eliminating from the federal courts cases with the requisite facts.

Finally, it should be recognized that the same analysis that calls for increased federal filing fees would also apply to certain federal prosecutorial functions. Where the third-party beneficiaries of federal prosecutions have much to gain, the Proposition's logic dictates that the government should forgo the prosecution until such beneficiaries foot the bill. Antitrust and civil rights violations fall within this framework, as may others. In this respect, the argument proves too much. As a matter of economics, combatting the perils of monopoly or racism seems far more cost-minimizing than having litigants pay for the heat, lights, and paper consumed in federal courts.

The forgoing critique shows the extent to which the traditional economic approach, as it has been applied in law, underestimates

charges is found in Miles, Taking Hostages: The Linares Case, HAstings CENTER ReP., July/Aug. 1989, at 4 (describing how the distraught father of a young child in a persistent vegetative state removed his son's respirator at the point of a gun because he was unable to afford the cost of obtaining a court order to terminate care, allowing the child to die).

108 See Bush, supra note 86, at 1019.

109 Id. at 910. 
normally incorporated costs considered in the real world. But the underlying theme of this Comment is that the federal courts, like the other two branches of government, should be accessible to all, within reasonable limits. Because the Proposition locks out cases that undoubtedly satisfy the Constitution's Article III requirements for "minimal personal involvement and adverseness,"110 examination of the subsidy itself, and its justifications, are in order.

There is no dispute that the access fee subsidy is overbroad. This Comment diverges from the Proposition only with respect to what should be done about it. In the absence of Congressional guidance regarding where the subsidy should be applied, some suggest that the courts themselves fashion guides. ${ }^{111}$ This suggestion is problematic, because judges are often ill-equipped to perform this appraisal. ${ }^{112}$

Some have argued that no subsidies are needed: if the litigant is unable to pay, access to the courts should be denied. Lee's position is that the lack of altruism on the part of litigants coming to federal courts justifies such an approach favoring access restriction. ${ }^{13}$ But whether the motives of litigants are to benefit the public or not, the externalities such litigation creates still exist. To the extent that this may be the chief value of the litigation, Lee's approach is unjustified.

Admittedly, non-economic costs and benefits are difficult to define. But this ground has already been covered, and some guidance exists. ${ }^{114}$ Despite definitional difficulty, the existence of costs generated by, for example, the oppression of fundamental rights and the disruption of human relations cannot be doubted. ${ }^{115}$ The problem, then, is to retain the insights that the economic analysis provides while at the same time accounting for non-economic costs. In an unusually insightful, but lengthy and complex analysis, Professor Baruch Bush retains the cost-minimization structure of economics,

110 Scott, supra note 40 , at 674 .

111 See id. at 682 . Scott argues that the courts often use standing analysis to control access by determining wherher Congress or the Founders intended to make a judicial forum available for the specific injury at bar. Scott finds this situation somewhat unpalatable because of the lack of coherent guidelines and the failure to focus awareness on the access control aspect of standing inquiry.

112 See id. at 682-83.

113 See Lee, supra note 46 , at 268.

114 See Bush, supra note 86 , at $942-43$ (noting that although the measurement is far from an exact science, even imperfect information is of great value); see generally Summers, Evaluating and Improving Legal Processes-A Plea for "Process Values," 60 CoRnell L. Rev. 1 (1974).

115 See Bush, supra note 86, at 939. 
but factors in both economic and non-economic costs. ${ }^{116}$ The relevant portions of Bush's analysis are implemented below by showing that costs relevant to the decision of whether to deny access are directly linked to the perceived objectives sought by the creation of federal court jurisdiction.

\section{The Federal Courts as a Public Good}

When a good or service becomes available, a decision must be made about whether it will enter the open market or be supplied only through government rationing. Goods and services (hereinafter "goods") entering the open market are called private goods; ${ }^{117}$ those dispensed by the government are called public goods. ${ }^{18}$ The distinction between the two is frequently lost because rarely are goods purely of either type. Yet this choice must be made with respect to almost all goods and services. As a result, advocates of one classification or the other focus on a particular feature of the good provided, claiming that feature as a rationale for the classification they advocate. This method reverses the logical order of analysis, as a consideration of Lee's "public good" analysis shows.

Lee defines public goods as "goods that must be equally available for use by all of the public." 119 He then describes such classic examples of public goods as a lighthouse and the common pasture in the center of town. ${ }^{120}$ Lee contends that the lighthouse presents no real free-rider problem ${ }^{121}$ but the common pasture does, ${ }^{122}$ and therefore is better suited for private allocation. ${ }^{123}$ Believing that federal courts are more similar to common pastures than lighthouses in that judicial resources are limited and consumable, he then classifies them as a private good, to be allocated by the market. Lee's discus-

116 See id. at 953-57. Professor Bush does not, however, claim to have isolated all the costs that might be incurred from some anticipated action. Rather, his contribution is in highlighting the importance of goal examination as a means to reveal costs. This differs from previous analyses, which compared various processes by their factors, regardless of how (if at all) these factors were related to the goals of the process.

117 See K. George \& J. Shorey, The Allocation of Resources 222-26 (1978).

118 See id.

119 Lee, supra note 46, at 267.

120 See id.

121 The use of light by one ship does not decrease the amount of light available to other ships. See id. at 268.

122 The consumable nature of grass means that there is nothing to prevent some townspeople from allowing so many cattle to graze that they consume more than their proportional share of community resources. See id.

123 See id. 
sion, however, obscures the fact that classification of any particular good as either public or private depends upon the uses and purposes of the good, which may vary. The designation of a good as public or private is, after all, merely a label describing the method of allocation that will be used. To determine the costs of such allocation one must look beyond the label.

An example will clarify this point. A swimming pool may be regarded as a private good to be allocated through the private market because use of the pool by one more person could affect the enjoyment of others in the pool. ${ }^{124}$ By focusing on the use of the pool at low occupancy level.s, however, one realizes that it also has the characteristics of a public good. When there are few people in the pool, an additional swimmer is unlikely to inconvenience those already in the pool. There is no disadvantage to distributing use of the pool as a public good without restricting access because use by additional swimmers does not affect the enjoyment of others. It is only when the pool becornes crowded that additional swimmers detract from the enjoyment of those already in the pool. Under crowded conditions, it might be appropriate to regard the pool as a private good and to exclude additional swimmers so as to limit their adverse effects. In addition to illustrating that classification of a good may change according to the conditions under which it is consumed, this example highlights a key difference between private and public goods: a good, such as the swimming pool, may be allocated as a private good only if it is possible to exclude others from using it.

This point is reflected in a more refined definition of public goods as "goods [or] services having the properties that (1) they cannot be provided to one citizen without being supplied also to that citizen's neighbors, and (2) once provided to one citizen, they can be provided to others at zero cost."125 It is implicit in the definition's first provision that "whether or not it is possible to supply a public good by private enterprise depends on the excludability characteristics of the good."126 Thus goods such as national defense should be supplied as public goods (since the ability to exclude one house but not the next from attack is limited), whereas the pool, under appropriate conditions, should be treated as a private good (since it is easy to exclude others by controlling admission to the area).

124 The example of the swimming pool as having characteristics of both a private and public good is adapted from K. GeORge \& J. ShOREY, supra note 117, at 223.

125 E. Dolan, supra note 35, at 95.

126 K. GEORGE \& J. SHOREY, supra note 117, at 223. 
Applied to the federal courts, we find that to the extent the public cannot reasonably be excluded from benefitting from court products, those products should be treated as public goods, but to the extent that such an exclusion is possible, court products should be treated as private goods. In short, by focusing on the intended purposes of the court's products, we can better determine whether to treat those products as public or private goods. Only after these purposes are determined should we apply the appropriate distributional economic model (that of a public or of a private good) to ascertain the optimal allocation method. Thus, the choice of a distributional model is much more complex than a facial determination that one ${ }^{\circ}$ good is "similar to" another, as it entails a full analysis of the uses of the good and the ability to exclude those uses and still achieve, at an acceptable level of cost, the goals for which the good is produced.

Posner, and other Proposition proponents, often see the federal courts as providing only two services:

One is dispute resolution-determining whether a rule has been violated. The other is rule formulation-creating rules of law as a by-product of the dispute-settlement process. When a court resolves a dispute, its resolution, especially if embodied in a written opinion, provides information regarding the likely outcome of similar disputes in the future. ${ }^{127}$

By limiting the function of the federal courts to providing only these two products, Posner is easily able to infer that exclusion is possible with limited costs. So characterized, the costs of restricting federal court access are limited to two categories: 1) loss of individual dispute resolution, and 2) loss of precedential effect for future litigants. Posner assumes that there are readily available substitutes to the federal forum, such as state courts and ADR, and that mitigation of costs, as bigger cases create better precedents, will compensate for any loss in the number of precedents. In effect, Posner sees the restriction of Court access as a relatively harmless solution. In light of the foregoing critique, this position myopically distorts the function of the federal courts. Without attempting to compile an exhaustive list, one can identify many more benefits of federal litigation than the present economic literature ordinarily discusses.

The specific statutory and constitutional grants of federal jurisdiction are, of course, starting points for determining what it is we expect of the federal courts. Beyond these, judicial discretion and (1979).

127 Landes \& Posner, Adjudication as a Private Good, 8 J. Legal Stud. 235, 236 
public attitudes and perceptions are useful indications of the intended uses and goals of federal adjudication. The courts themselves have recognized the broad functions of litigation by according standing to plaintiffs with non-economic claims involving political, ecological, and religious-based issues. ${ }^{128}$ As demonstrated below, the various benefits of federal court output do not allow for the ready exclusion of the public. Therefore, federal courts are more aptly characterized as public, rather than private goods, and should be allocated accordingly.

As a general matter "[a]]dequate adjudicative services are central to the maintenance of a civilized society." 129 Having ramifications far beyond Posner's "rule formation," this role of the federal courts is a recognition that the legitimacy of society's institutions is premised upon fair and adequate dispute resolution. ${ }^{130}$ Public acceptance of governmentally imposed resolution systems arguably comes in exchange for federal provision of the forum wherein such settlements occur. ${ }^{131}$ As Professor Bush explains: "If a disputant feels he is entitled to some assistance in handling his dispute, and none is forthcoming, ... he may well feel betrayed by society and question the legitimacy of its institutions." 132

It is not enough for ?osner to respond that state courts and ADR equally serve this legitimating purpose. First, such a decision belongs to Congress. Second, Posner's view, as already mentioned, ignores the various differences between the federal and state or private systems that could lead litigants to believe that they are receiv-

128 See Scott, supra note 40, at 675-76.

129 Alschuler, supra note 69, at 1810.

130 See Bush, supra note 86 , at 919.

131 Non-conventional "economic analysis" provides further insight regarding the perceptions various levels of access to federal courts may produce. Under Marxist economic theory, the irstitutions created in a capitalist system (such as courts) serve but one purpose: to enforce the will of the bourgeosie. By these institutions, the alienation of the proletariat is effected, thereby creating the driving force that Marx predicted would bring the eventual overthrow of capitalism. See generally R. Heilbroner, Marxism: For and Against (1980). Marx's description of the role of courts in society serves as a warning to those who would close the courtroom doors through increased court access fees. One need not embrace Marx's prediction of "doom to Capitalisrn" to understand the perils from public displeasure at a courtroom "lock-out." As Weinstein notes: "Once the courthouse door is shut, some groups may have no alternative but to storm the entire building." Weinstein, supra note 68, at 1922.

132 Bush, supra note 86 , at 919 ; see also Weinstein, supra note 68 , at $1920-21$ (arguing that the legitimacy of the courts and the judiciary in the eyes of the public depends upon it feeling able to vindicate individual rights through the system). 
ing an inferior substitute. ${ }^{133}$ One reasonably may assume that these differences play as much a role in plaintiffs' forum choices as do access fee costs.

The federal court system also provides uniformity of federal rights across the nation. Citizens should not encounter varying levels of state condoned sexual or racial discrimination as they travel throughout the country. In general, the value of federal rights is that they:

impose norms that may be politically unpopular in the locality or that impose costs on actors-such as private businesses or state governments-who may be particularly influential in the area. Federal courts staffed by individuals enjoying lifetime tenure are inevitably going to be more receptive to the assertion of claims based on such rights. Federal courts are also more likely to be familiar with federal law, conditioned to viewing federal law as a unitary system, and hence more attentive to pronouncements in other circuits. ${ }^{134}$

That the attainment of this goal can be achieved only through broad, rather than restricted, access to the federal courts is beyond dispute. The enforcement of such norms must apply in cases involving small, as well as large, monetary stakes, otherwise they will not constitute norms at all.

Further, the federal judiciary, as the third branch of the federal government, provides yet another avenue for citizens to influence the way that their government works. Leubsdorf comments that:

the more one recognizes the courts as creative participants in shaping governmental policy rather than simply as enforcers of legislative rules against the individual, the more one should protect the rights of citizens to enter the courthouse and argue before the judges." 135

Because "access to the legislature and the executive has rarely been questioned,"136 and the courts are an equal, though perhaps often overlooked, partner in our government, one should closely scrutinize limitations restricting access to the federal judiciary. In addition, Leubsdorf notes:

Judges can become better informed than most officials about many problems; litigation can provide more public access than other methods of decisionmaking; courts have sometimes been willing to

133 See supra notes 77-85 and accompanying text.

134 Estreicher, supra note 64 , at $578-79$.

135 Leubsdorf, supra note 26, at 598.

$136 \mathrm{Id}$. at 597. 
act when other institutions were afraid or deadlocked; and courts have sometimes protected groups too powerless or shunned to find relief elsewhere. ${ }^{137}$

Open entry to the federal courts for all federal claims is the best way to keep the federal judiciary informed about the concerns of society, ${ }^{138}$ and may help to offset any imbalances in access to the other branches of government.

Litigants sometimes need federal courts to correct serious problems that the other branches of government are unwilling or unable to address. ${ }^{139}$ The "bigger is better" mentality of Posner obscures the fact that "smaller cases are often microcosms of larger problems and often focus the judge's thinking on these problems most effectively." 140 Federal courts serve as an important escape valve for the social problems of the politically powerless. This calls into question the wisdom of exclusion.

Yet another goal promoted by the federal courts is government consistency through constraints on government officials. By enforcing the "rule of law," federal courts help ensure that common values, as expressed through legislation, are applied with fairness and predictability: "[J]udges apply the rules in the light of shared understandings and commitments and of personal values. If the participants share enough of these understandings, this process can yield at least some predictability and consistency." ${ }^{41}$ Although one may quibble over the courts' effectiveness in performing this function, such disagreement differs from saying the function is unnecessary and that it is unimpaired by restricted court access.

Further, ready access to federal courts advances the development of constitutional law. Public involvement in constitutional adaptations is of value in itself because fundamental rights are not necessarily as static as the term "fundamental" implies. The right to interstate travel was arguably less "fundamental" before the advent of the railroad and other means of rapid interstate travel made such travel integral to daily life. Although not approving judicial activism, this position recognizes that the application of constitutional princi-

137 Id. at 599.

138 See, e.g., Weinstein, supra note 68, at 1918 (suggesting the great importance of small diversity cases in keeping federal judges abreast of state law and in touch with the concerns of the public).

139 See, e.g., Brown v. Board of Education, 347 U.S. 483 (1954) (forbidding school segregation when the executive and legislative branches were unwilling to act).

140 Weinstein, supra note 68 , at 1918.

141 Leubsdorf, supra note 26 , at 595. 
ples involves more than Judge Bork's admonition to follow the "framers' values."142 Exclusion inhibits the development of new constitutional law and impedes the refinement of existing constitutional law. Formal amendment of the Constitution should not become the substitute for the minor adjustments that occasionally are needed when new social problems arise. ${ }^{143}$

The forgoing purposes add significantly to the two important purposes Judge Posner identified: individual dispute resolution and precedent creation. ${ }^{144}$ But one final point regarding federal caseload resolution deserves note. Proposition proponents are strongly motivated by the "free-rider" problem that occurs because litigants are only a small percentage of the taxpayer population. Yet, closer examination shows that this problem is neither as large as it first appears nor adequately addressed through indiscriminate diversion. Present figures show that for every eight cases that enter the pre-trial stage or beyond, ninety-two settle or are otherwise disposed of without trial. ${ }^{145}$ This disparity between cases filed and cases actually litigated indicates that the free rider problem is probably overstated. ${ }^{146}$ Although federal judges have become increasingly involved in the pre-trial stages of litigation since the 1983 amendment to Rule $16,{ }^{147}$ a substantial amount of a court's time is spent on cases in the trial stage (or beyond for appellate courts). ${ }^{148}$ The

142 See R. Bork, Tradition and Morality in Constitutional Law (1984) (Francis Boyer Lecture on Public Policy).

143 The current debate concerning whether the U.S. Constitution should be amended to prohibit flag burning provides a striking example. See, e.g., Loewy, The Flag-Burning Case: Freedom of Speech When We Need It Most, 68 N.C.L. REv. 165 (1989) (discussing the dangers of a constitutional amendment); Terranella, Political Drive for Flag Amendment is Dangerous Folly, Legal Times, July 31, 1989, at 20, col. 3 (discussing problems inherent in an amendment to protect the flag).

144 Ironically, Professor Brunet merely adds the role of courts as producers of social change to Judge Posner's list and concludes that "courts should be viewed as a public good." Although Brunet's brief discussion supports much of the forgoing discussion in text, he, too, makes the premature leap from "good recognition" to "appropriate allocation." See Brunet, Measuring the Costs of Civil Justice (Book Review), 83 Mich. L. REv. 916, 932-34 (1985).

145 These figures are interpolated from District Court figures in ANNUAL REPORT of the Director of the Administrative Office of the United States Courts, Table C5B (1987).

146 Rapid increases in federal court filings are often cited by Proposition proponents to support the caseload crisis claim. See, e.g., R. PosNER, supra note 38, at 66-67 (figures 3.1 and 3.2).

147 The amendment expanded judicial involvement by clarifying the court's scheduling and managerial duties regarding pre-trial conferences. See FED. R. CIv. P. 16 and advisory committee's note.

148 See J. Kakalik \& R. Ross, Costs of the Civil Justice System: Court 
externalities of federal litigation "compensate" taxpayers for their financial support of those litigants who run the gauntlet. ${ }^{149}$ Thus, continued insistence on a free rider problem likely masks a normative objection to "frivolous" litigation at taxpayer expense. The problem of frivolous litigation, however, is better addressed by the precision of federal judicial oversight (e.g. Rule 11 sanctions) than by a callous diversion oblivious to the merits. ${ }^{150}$

The categorization of federal litigation as a public good is not without problems. Recalling the second part of the definition of public goods discussed above, ${ }^{151}$ one realizes that public goods are not, in practice, supplied irrespective of their costs to produce. The theoretical definition of public good price is effectively zero. Stated another way, "there is non-rivalry, or a zero opportunity cost, in consumption." 152 Therefore, one is provided little insight into what should be the optimal level of supply. ${ }^{153}$ Conversely, private goods are rationed by price, which determines the amount a supplier will supply. But this need not be an insurmountable barrier. There is a supply and demand function for public goods. ${ }^{154}$ Although the analysis lacks the exactitude that dealing with monetary sums provides, rationally determining an experimental range of optimal supply is still possible. Compared to Posner's alternative, in which substantial

Expenditures for Various Types of Civil Cases 37 (1983) (describing a study of state and federal courts finding that civil jury trials average "two to five days of judgetime" and non-jury trials require "one day or less of judge-time").

149 See supra text accompanying notes 133-43.

150 Prisoner petitions collaterally attacking their convictions clearly constitute the largest class of actions subject to the label of "frivolous." Recognizing the constitutional implications of further denying access to those incarcerated, restricting the grant of in forma pauperis ("I.F.P.") status is preferable to outright diversion for addressing the "frivolous" litigation problem. See, e.g., In re McDonald, $109 \mathrm{~S}$. Ct. 993 (per curiam) (holding petitioner earning $\$ 300$ per month unable to proceed with forma pauperis filing petitions for extraordinary writs due to numerous prior frivolous filings), reconsideration deried, 109 S. Ct. 1636 (1989). Such determinations are made on a case by case basis and focus specifically on the action at issue. Nonfrivolous prisoner petitions would certainly fare worse under the Proposition.

151 See supra text accompanying note 125.

152 K. GEORge \& J. ShOREY, supra note 117, at 222.

153 See generally Posner, Theomes of Economic Regulation, 5 BELl J. Econ. \& MGMT. ScI. 335, 340 (1974) (noting in market theory that efforts of individuals to promote their self-interest through transacions result in an efficient allocation of resources); see also Scott, supra note 40, at 671 ínoting that "[t]he subsidization of judicial services creates a problem in determining not only the proper amount to provide, but also its distribution.").

154 J. Buchanan, The Demand and Supply of Public Goods (1968) (examining the demand and supply of public goods and, therefore, implying that such a structure exists). 
economic and non-economic costs are ignored, the risk of error here is minimal. Leaving supply at the present level may be possible if criteria are developed for more effectively allocating the subsidy (i.e. through guidelines regarding types of cases or litigants).

But what if the public good analysis leads to the conclusion that the federal judiciary must be expanded? Are the structural difficulties that Posner sees controlling federal judicial expansion an impediment? To the contrary, imaginative methods can be found whereby the federal caseload can be either expanded or restructured if the public good analysis deems it necessary. The creation of an intermediate appellate court or more specialized courts, similar to the Tax Court, are examples of such methods. Although no particular suggestion is endorsed in this Comment, the possibilities are not as limited as Posner suggests. Despite Posner's warnings, one wonders whether "a doubling of the existing . . . judgeships [would] so cheapen the coin that men and women of distinction would not be attracted to the federal bench?" 155

And if no such suggestions are forthcoming? Admittedly, courts lack guidance about where the subsidy should be applied when caseload pressures dictate that it cannot immediately be supplied to all. The congestion and delay in federal courts indicate that Congress is "unwilling to supply the amount of judicial services that is in fact demanded at the artificially low prices charged to litigants by the courts." 156 But courts can, and do, continue to operate and fulfill their functions even in the absence of Congressional willingness to make these hard decisions. From an economic perspective, delay costs already divert some cases from federal court. Admittedly, such a response is far from perfect, but it may provide some impetus for those desiring greater court access to press for legislative action. Posner's alternative, to a greater extent than delay costs, drives litigants out of court in blatant disregard of the actual costs involved. Telling someone she must wait to get what she needs is better than telling her she must look elsewhere for assistance. The former, if sincere and within reason, would less likely undermine confidence in the legitimacy of the system than the latter.

A final problem may exist in the argument that "expansion of access to . . . courts simply increases the dependence of the powerless on professionals." 157 The criticism is interesting in that the

155 Estreicher, supra note 64, at 577 (footnote omitted).

156 Scott, supra note 40 , at 672.

157 See Abel, supra note 65, at 490 . 
ready availability of courts as dispute resolution mechanisms tends to undermine other peaceful methods of self-help (possibly including ADR), which are sometimes effective without the presence of trained and expensive legal advisers. But this problem seems more a problem of too much law, than too much access. Accordingly, the remedy lies elsewhere than the courthouse door. Furthermore, even nonlegally based dispute resolution systems frequently draw from legal precedent as guides in their actions. ${ }^{158}$

\section{CONCLUSION}

Lee's and Posner's concerns about the use of the court access subsidy are not without merit. But the analysis above indicates that since federal court output must be disseminated widely to serve the goals of federal forum creation, the method whereby we distribute such output differs from that which the Proposition proponents advocate.

The bottom-line illustrates that access to the federal courts serves many different social goals. When access is denied, tremendous social and economic costs are imposed on the public. Although specific valuation of such costs is not always reducible to dollar figures, the breadth of the civil and social rights affected provides some measure of these costs. This analysis implies that another unit of measure needs to be used in the cost-minimization approach to account for all the costs involved. Baruch Bush's framework is one such attempt; others are certainly conceivable. Therefore, federal judicial services can efficiently be allocated under public good theory.

Treating federal courts as public goods does not obviate the need to minimize the costs of their provision, but such cost-minimizing is not a "procedural" matter. The weight attached to the various costs of supplying or not supplying federal court access cannot be reduced to an economist's diagram until the substantive scope of such costs are determined.

Judge Weinstein summarizes the policy arguments that his counterpart Judge Posner chooses to minimize and, in so doing,

158 See Brunet, $A$ Study in the Allocation of Scarce Judicial Resources: The Efficiency of Federal Intervention Criteria, 12 GA. L. REv. 701,707 n.32 (1978). Brunet uses this factor to show that the subsidy of federal courts also serves to subsidize ADR to a limited extent. But this point does not undermine the reference here that the subsidy might also be justified for its value outside of formal dispute resolution systems. 
highlights the need to treat the court access issue as something larger then a "procedural" pricing problem:

[I]f cases are growing in the federal courts, so be it! That is what judges and courts are there to do: to hear cases. We are public servants pledged to do justice, not exalted elites who bless the masses with such bites of judicial time as we deign to dole out.... On balance, the social costs of adding personnel are likely to be much smaller than the social costs of frustrating important civil and commercial rights. ${ }^{159}$

Weinstein demonstrates an understanding of the scope and complexity of the costs arising from "barriers to litigation." This provides a clearer perspective from which to view the issue of how to control access to the federal courts.

159 Weinstein, supra note 68 , at $1909-10$. 
